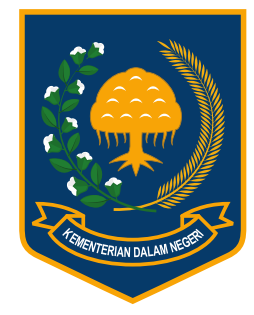

Jurnal Bina Praja 8 (1) (2016): 59-68

Jurnal Bina Praja

e-ISSN: 2503-3360 | p-ISSN: 2085-4323

Accreditation Number

735/AU2/P2MI-LIPI/04/2016

http://jurnal.kemendagri.go.id/index.php/jbp/index

\title{
MANAGING THE IMPACT OF SMOKE HAZE DisASTER: RESPONSE OF Civil Society GROUPS Towards Jambi Provincial Government Performance
}

\author{
$\operatorname{Arfan}^{1, *}$ \\ ${ }^{1}$ IAIN Sulthan Thaha Saifuddin Jambi \\ Jl. Jambi-Ma Bulian KM 16 Sungai Duren Jambi
}

Received: 23 February 2016; Accepted: 30 April 2016; Published online: 31 May 2016

\begin{abstract}
Smoke haze from forest and land fires in Jambi in 2015 had led to various reactions. The low response from the provincial government led by an Acting Governor received various criticism and protests from civil society groups. This study examines the impact of 2015' haze in Jambi and describes civil society groups' responses toward the government "transition" of Jambi province performances regarding 2015 smoke haze. Through observation of the relation and activities of the two sides: government and civil society, and open-ended interview with a representative of civil society groups, the results showed that the barrier is the absence of a national disaster status. Acting Governor and Regional Working Unit (SKPD) have a limitation in funding, equipment, and human resources to conduct fire fighting and are unresponsive in treating the haze victims. The persistence of civil society groups which work independently to help victims and encourage the government to be more responsive led to the issuance of Local Regulation on Forest and Land Fires. Finally, this study recommends the government of the Republic of Indonesia to formulate task and function certainty of the central government and Acting Governor in the handling of smoke haze under the condition without national disaster status.
\end{abstract}

Keywords: smoke haze disaster management, Jambi Government, civil society groups.

\section{INTRODUCTION}

The incidence of El Nino Southern Oscillation (ENSO) in 1997 has led to the dry season, forest fires, and caused smoke haze. The phrase 'haze', 'smoke' and 'smoke season' become new words to describe the impact of El Nino in 1997. 45,600 square kilometer area consisted of burnt plants. Especially in Sumatra and Kalimantan (Heil, A. and Goldammer, J.G., 2001). Tacconi (2003) even estimated that the burnt area was 25 million hectares. The impact of forest fires and haze was felt by Malaysia, Thailand, and some Southeast Asian countries. Khandekar, et. al. (2000) called forest fires and haze in 1997 as a lethal combination of natural behavior and people's action (men made hazard). Although deadly, smoke haze and severe forest fires in 1997 caused by ENSO was repeated again in 2015. Jambi which has a total area of 5.1 million hectares become one of the contributors to the smoke caused by forest and land fires.

Smoke haze that hit Jambi and several other regions in Indonesia in the middle of August until November of 2015 has left a bitter memory. Sulthan Thaha Saifuddin Airport in Jambi was closed for about 2 months. All the employees of the airlines still worked while waited for the information on the possibility of airplanes to depart from Jakarta and return. For two months without certainty for a flight from and to Jambi, the flight customers must go through additional 7 to 8 hours of travel from and to Jakarta because they had to go up and down the plane in Palembang. Sultan Mahmud Badaruddin II International Airport in Palembang is equipped with ground mist detector around the airplane runway so that the flight was smooth although there was a smoke disruption. The public transportation from Jambi to Palembang gained profit, while the sellers, taxi drivers, and porters in the area of Sulthan Thaha Saifuddin Airport in Jambi were suffered from loss.

In education sector, although it caused dilemma of lesson hours, the kindergartens and primary schools starting from the middle of August

\footnotetext{
* Corresponding Author

Phone : +62811374802999

Email : arfan_rv@yahoo.com
} 
were situationally closed, especially when the haze was getting denser and were opened again when the haze was disappeared. The Mayor of Jambi made circular notes more than three times to instruct the Heads of Schools to close and tell the kids to go home in lesson hours. Even, the circular notes were made conditionally every day within minutes and spread through multimedia to the heads of schools. As the initial countering measure, the students were provided with simple masks to face the air pollution from smoke haze. While the index of air pollution at the end of October 2015 was around 500 to 700 , far above the normal air quality standard of 0-50 air pollution index (API). API or air pollution index above 200 is considered toxic and harmful air according to the Decree of the Minister of Health of the Republic of Indonesia No. 289/MENKES/SK/ III/2003 that explains the phase of air pollution prior to forest fires, during forest fires, and after forest fires.

Smoke haze began in the middle of August 2015. The source of the smoke was forest and land fires, especially in peatlands. According to the data of National Board for Disaster Management (BNPB) at the end of August 2015, hot spots were found in in South Sumatra, Jambi, Riau, and Bangka Belitung. The total number of hotspots in Sumatra were 178 spots with the details of 80 spots in South Sumatera, 69 spots in Jambi, 10 spots in Bangka Belitung, and 5 spots in Riau.

On 14 September 2015, hotspots in Jambi Province alone had reached 87 spots as illustrated by satellite image maps of Terra \& Aqua analyzed and spread by Indonesia Conservation Community (KKI WARSI) through social media and printed media release (refer to a map below).

Hotspots that were growing in number and smoke that was getting denser, according to some civil society groups, were not really responded, if not to say ignored, by the government of Jambi Province and the Central Government (Interview with Ipg, Volunteer of KJMA, 17 January 2016). The government's attitude that was considered slow made some civil society groups, consisting of farmer assistant activists, farmers, nongovernment organizations, reporters, artists, and academics, protest the government. They organized themselves in two unities, Jambi Coalition against Smoke (KJMA) and Smoky Jambi. The protests were conducted in the form of open campaign in mainstream media and social media, and through dialogues with the government. On the other hand, the government of Jambi Province, which was led by Acting Governor, seemed to be on adaptation process, was very cautious in making any policy and slow in making coordination with the municipal and district governments in Jambi Province, and also on coordination with the central government.
The society protest to the carefulness of the Acting Governor in Riau Province was even harsher. Because of the denser smoke and the slow action of the Acting Governor, on 23 October 2015 civil society groups, including academic, came to urge the Acting Governor to act fast in countering smoke, make evacuation house for smoke victims of children and pregnant women, or quit. While in reality, in the beginning of September, in a media report of Riauterbit.com, the Acting Governor of Riau was summoned to meet President Joko Widodo because he was considered slow in handling the smoke.

The relation of civil society and the government in Jambi was getting tenser when the smoke was getting denser. The activities of government organizations, Indonesia Military (TNI), and religious organizations such as istighosah, istisqa followers (praying for rain) were more or less play a role in driving the tense relation to the shared act of surrender to the condition.

Before 2015, the most alarming event of smoke haze in Indonesia was in 1997. The lack of information on the cause of forest and land fires gave birth to the surrender of people. Many articles were created from the analysis of smoke haze event at that time. Even, on the following year, when reformation was started, the articles about smoke were keep on being made and opened the horizon on the causes and impact of smoke in 1997, either in ecological issues created, like the one written by Dennis, R., et. al. (2000), Sargeant, H.J. (2001) that connected smoke with the intensity of palm oil plants; Sudarmadji, T. (2001) and van Nieuwstadt, M.G.L., et. al. (2001) on the correlation of forest fire with logging activities in East Kalimantan, and the impact of haze in 1997 to health as writer by Osterman, K. and Brauer, M. (2001). While articles that relate smoke haze with the economic effects it caused are like the one written by Oosterman, A. and Widayat, D. (2001) on the economy of Batu Ampar Community, and Tacconi, L. et.al (2002) on the impact of haze to socio-economy of the people in Central Mahakam East Kalimantan. In addition to ecological, health, and economy themes, the themes of legal and regional and international relations were also highlighted, like an article edited by Qadri, S.T. (2001) on the issue of Asian Development Bank entitled "Fire, Smoke and Haze: The ASEAN Response Strategy" and a graduate thesis of Suyastri in Universitas Gajah Mada (2009) that related the smoke in Riau with ASEAN treaty on the agreement on transboundary haze pollution that was yet to be ratified by Indonesian Government, and also an essay by Deni Bram $(2011,2012)$ about the punishment against corporation crime that has crossed the country through the event of smoke haze.

Some of these essays and researches above are 
emphasizing on the attention towards the impact of forest and land fires in Kalimantan, Sumatera, and Indonesia in General. But this study specifically limited its discussion on the event of smoke in 2015 and the impact in the context of Jambi, as well as explored daily relation between civil society groups and the government in the effort to manage the impact of smoke. Some issues of health and environment in the local context of Jambi will also complete the illustration of the smoke event in Indonesia in the past 2015.

\section{METHOD}

This study uses the qualitative method. Primary data were obtained through observation and open interviews. Observation is carried out towards the policies and performance of Jambi provincial government in managing the impact smoke haze and the activities of civil society groups to overcome the impact of smoke haze and to respond the government's work. Interviews were conducted with four personnel of volunteers from Jambi Coalition against Smoke (KJMA). Secondary data were obtained from earlier studies that have been published in research journals, research reports, theses, and news in the media related to the theme of smoke and managing smoke haze.

\section{RESULT AND DISCUSSION}

\section{A. Smoke Origins and Impacts}

Jambi community and some other smokeaffected area in Indonesia, were not only in 2015 experiencing "smoky season". Almost every year land fires happen. However, the event of smoke that was most acute after 1997 just happened again in 2015. The reason was almost the same, because of the presence of El Nino in some tropical regions close to the sea in the world plus the mistake of allowing large-scale space for water flows and peatlands to be investments in palm oil and timber plantations.

El Nino is the interaction impact between the ocean sea and the atmosphere which is expected to come once every four years, without the possibility for prevention by human and its impact can only be tackled (Ilahude and Nontji, 1999). In fact, according to Ilahude and Nontji, before the severe dry season and smoke haze in 1997/1998, El Nino already caused dry season for 33 months in 19391942. All regions in Indonesia at that time were flammable, forest and agricultural products were declined. The context of smoke in 1997/1998, according to a research by Sargeant (2001), was due to massive investment in the agriculture sector of palm oil monoculture in half the swamps and peatlands. The revival of palm oil business increased the chances of deforestation, the transfer function of water infiltration areas, and the opportunity of the increasingly severe smoke of palm oil plantations after 1997 (Casson, 2000). The stimulus for investment in the sector of industrial timber plantations and palm oil plantations at the national level, and also the making of spatial policy in Jambi province to be dominated by those two sectors, in addition to the mine site and three national parks that also dominated Jambi spatial. According to Casson (2000), Indonesian government's desire during Suharto era to be the "champion" of palm oil plantations in the world make this sector become more massive. Although weakened briefly when the economic crisis happened, investment in palm oil plantations revived in the reformation era.

The area of Jambi Province as a whole is 5.1 million hectare. Looking up regional licensing data, palm oil plantations controlled 24 percent of the area (1.2 million hectares), which consists of plantations with Cultivation Rights Title (HGU) and still active as well as plantation companies that have a license but no longer in operation. Production forest, through Industrial Plantation Forest (HTI) companies, own 1.3129 million hectares or 26 percent of the area of Jambi, while Kerinci Seblat National Park, Bukit Dua Belas National Park, and Bukit Tigapuluh National Park own 870.250 hectares or 17 percent of the area. Meanwhile, community living area is approximately 9-18 percent of the existing area in Jambi. The estimation of this 18 percent of space for the community is if rubber plantations owned by companies are included as part of people's rubber plantations.

As a traditional plant, historically rubber is also the main support of Jambi community's economy since the plant was introduced in 1904 with the seeds imported from Malacca (Scholten, 2008: 323). Even, according to Scholten, rubber plant was what made people of Jambi prosperous at the beginning of 20 th century and was the main income because it earned 46 million guilders in 1920s decade and contributed 90 percent of Jambi's export commodity. As mentioned above, the traditional rubber plant's space now is defeated by palm oil plant owned by some big companies. It is recorded that business groups of Sinar Mas, Raja Garuda Mas, Bakrie, Makin and Wilmar own subsidiaries of palm oil plantations in Jambi Province.

The paradigm of palm-based agricultural development during the era of Governor Zulkifli Nurdin era has indeed been launched as an effort to encourage economic prosperity for the rural population. At that time, the plantation was a jargon of development with the theme 'A Million Hectare Palm Oil'. However, recently civil society groups strongly protested the idea with the reason of the environmental impact that will be generated as well as the potential for social disturbance in rural areas 
due to land monopoly by corporations. Finally, the 'A Million Hectare Palm Oil' campaign dimmed as the construction of a discourse on the importance of ecological care to global climate change and the possibility of clean air production (carbon trade) from tropical countries like Indonesia under the Kyoto protocol in 1997. The Kyoto Protocol resulted in an international convention on climate change.

Historically, palm oil plantation in Jambi has existed for around 30 years and has made social changes in villages around plantation (Arfan, 2007). In the 1980s, palm oil commodity was introduced. According to Zulkifli (2002: 2), the arrival of palm oil in Jambi was in 1983, which was through a scheme of People Main Plantation (PIR) of 500 hectares. The PIR scheme was implemented by PTPN VI in Batanghari District. Private plantation companies then came to follow the existence of PTPN. The companies with Forest Utilization Rights (HPH) in Jambi were also involved in continuing their license by requesting new palm oil plantation permit like the area of HPH Asiatic Mas (PT Bangun Desa Utama) which then became the palm oil plantation area of PT Asiatic Persada. Therefore, after 1985 the plantation of palm oil kept increasing rapidly.

In 1995 the total area of palm oil plantation in Jambi had reached 122.420 hectares with the total production of raw palm Oil (CPO) amounted to 106.761 tons. The area covered 5 types of the plantation: government plantation through State-Owned Entreprises (BUMN) or PTPN, private plantation, people plantation included on cooperation scheme with companies through cooperatives, a limited plantation owned by transmigration residents also through cooperation scheme with companies through cooperatives, and lastly small plantation owned by the farmers managed individually. At the end of 2000, palm oil plantation area had doubled up from 1995, which became 296.010 hectares. Even, in Sumatra area, Jambi was the fourth biggest province related to the area of palm oil plantation after North Sumatra, Riau, and South Sumatra (Asnelly, 2004: 30). In 2001, as stated above, the Governor of Jambi stated his idea on "A Million Hectare Palm" mega project. According to the Department of Plantation of Jambi Province then (2001), to meet the total of 1 million hectare of palm plantation, the government of Jambi has made Land Directive Letter (SAL) of 543,178.00 hectares which included longstanding plantation business permit but not yet operated and the area with expired plantation business permit but was never used by the companies. The plan of this mega project could not be separated from the spirit of regional autonomy, where regions were allowed to get Owned-Source Revenue (PAD) as much as possible. But the plan became controversial if overlay was conducted with smoke haze in 1997.
The haze in 1997 was also from the flammable areas and at that time, the palm plantations were not as much, which was known as a water-thirsty plant. Therefore, the ecological and climate bases became the support for environment organizations to reject the idea "One Million Hectare Palm" to find its momentum.

1997 and the beginning of 1998 were the years of worst forest and land fires, which burned 25 million hectares of forest and land in the world (Tacconi, 2003). Not only in Asia's sphere, Latin America also suffered from a forest fire. The smoke of forest and land fires as a result of El Nino or ENSO (El Nino Southern Oscillation) had reached Indonesia. The impact of the forest fire was, aside from environmental issues such as the decrease of carbon ingredient previously produced by plants and trees, also in economy, health, and social. Children, breastfeeding mothers, pregnant women, and elderly were those who got impacted the most. The total loss of Indonesia as a result of forest and land fire in 1997/1998 according to BAPPENASADB (1999) was 144 billion US Dollar. The impact of smoke haze in 2015 in Jambi was estimated to cause loss amounted to 2.6 trillion Rupiah (Interview with Iqbal Zainuddin, volunteer of KJMA, 23 January 2015). According to Iqbal, Jambi Coalition against Smoke (KJMA) consisting of 26 agencies which own capacity to calculate the loss caused by the smoke with a method commonly done by them, namely valuation of natural resources economy.

According to the calculation data from satellite image analysis by the division of Geographical Information System (GIS) of KKI WARSI in Jambi, forest, and land fires that hit Jambi on 20 August 2015 from peatlands area of 9.149 hectares were only from two districts, namely Muaro Jambi and Tanjung Jabung Timur. The number were growing. Based on the observation by KKI WARSI on 5 September 2015, the burned area has become 33.745 hectares that included hotspots in the area of plantation companies, industrial plantation forest owned by companies, and the area of Berbak National Park in Tanjung Jabur Timur. On 14 September, there were 87 hotspots spread in 8 districts in Jambi Province (look at the above hotspots map). The hotspots were newly subdued in the second week of November as a result of natural rain.

The smoke haze in 2015 not only hit Jambi. Smoke in Palangkaraya is the smoke with largest particulate levels if compared to the other areas in Indonesia affected by land fires. Media report of Kompas.Com, on 23 September 2015, the particulate of PM 10 in Palangkaraya's air ever reached 1,995 micrograms in the Air Pollution Standard Index (ISPU) on September 22, 2015. In fact, the high ISPU caused the ISPU gauges must be restarted. In theory, the air with particulate of PM 10 highly that was 
concentrated in Palangkaraya is very dangerous and will lead to pneumonia and acute bronchitis, both in children and adults. These two diseases are the high ranks of Respiratory Infection or ISPA (Fardiaz, 1992).

Just like Palangkaraya, the smoke with a high content of particulate matter of PM 10 had filled the air of Palembang on September 30, 2015. Palembang BMKG recorded the content of particulate matter of PM 10 in the air in the area of Sultan Mahmud Badaruddin II airport of 800 micrograms at six o'clock in the morning on September 30, exceeding the threshold of reasonable pollution around the airport, which is 150 micrograms (http:// news.liputan6.com/read/2329720/gubernursumsel-yakin-kabut-asap-palembang-berakhiroktober-2015).

The impact of smoke in Sumatra and Kalimantan have also been taken by monsoon wind transition to cross into Malaysia and Singapore. In 1997, Sumatra smoke caused reduced visibility and a decline of clean air in Kuala Lumpur and the surrounding areas. While the smoke from the Southwest of Kalimantan dominated the smoke of Southeast Sumatra (South Sumatra, Riau, and Jambi) in impacting air pollution and decreased visibility on the highway of Singapore that year (Lawrence, et al., 2001). However, in 2015, land and forest fires in Sumatra and Kalimantan were still repeating the old story. At the end of September, the smoke had shrouded Putrajaya, Malaysia and the smoke of Southeast Sumatra were carried by winds up to Singapore. The only difference was the smoke of Kalimantan moved northeast to the regions of East Malaysia, Negeri Sarawak, and Sabah. While transnational smoke from Southeast Sumatra to Kuala Lumpur and surrounding areas was dominated by the smoke of South Sumatra province. When researchers came to Kuala Lumpur at the smoky season, schools were closed for two days. While the Environmental News Agency report of Mongabay.com stated that Air Pollution Standard Index (ISPU) in Kuala Lumpur is in the range 117146 or in the status of not healthy, Sarawak 126156 was also unhealthy, while Singapore was still in moderate number of 81-92 ISPU, The visibility in the administrative capital of Malaysia, Putrajaya was approximately 700 meters.

\section{B. Jambi Government's Performance towards the Impact of Smoke Haze}

According to one volunteer of KJMA (Interview on January 23, 2016), Jambi suffered from land fire almost every year. The monitoring record of Indonesian Conservation Community (KKI-WARSI), since 2010 to 2015 the hotspots continue to be monitored during the dry season and the majority were in the monoculture company's concession area, both in palm oil plantations and concessions for industrial forest plantation or HTI. In 2010, the results of satellite observation in the level of credibility of 80 percent, there were hot spots in the concession area of 16 companies and eight palm oil plantation companies. In 2013, the hotspots observed in the area of 29 palm oil plantation companies and 16 HTI companies. Meanwhile, in early September 2015 hotspots were in almost 40 areas of palm oil plantations and 17 HTI companies with the most number of hotspots in the area of PT Lestari Dyera Hutani as much as 126 SPOTs (KKI WARSI's document in satellite observation map).

Information on the possibility of prolonged dry season due to El-Nino and the projection of massive land fires and smoke incidence in 2015 was broadcasted by the Meteorology and Geophysics Agency (BMKG). For instance, it was reported by sindonews.com thatin June, Deputy of Meteorological Division of BMKG stated the possibility El Nino until November 2015. However, the preparation policy to cope with the land fire situation and the preparation of health care in disaster and post-disaster phases comprehensively by the government and the plantation concessionaire companies and industrial plantation forest may seem slow.

In local policy, Jambi Provincial Health Department raised a debate. The increasing number of smoke victims in October 2015, especially among toddlers, was still denied by Jambi Provincial Health Department (see the case of Nabila and Digo below). The denunciation may be due to limited funding and health workers, but instead, it was against the statement of the Minister of Health of pneumonia that arose from dense smoke from forest and land fires in 2015. The sectoral work of Jambi Provincial Health Department (DINKES) also occurred in Jambi Province Regional Disaster Management Agency (BPBD) as well as other regional work units (SKPD). Although they created the impression of working hard, the sectionalization of the performance of local officials in Jambi province was also due to Joko Widodo's government policies that do not consider the smoke incidence that got denser every day since late August to October, a national disaster.

Nationally, the Government of the Republic of Indonesia in the era of Susilo Bambang Yudhoyono era appeared to be more responsive versus the leadership of Joko Widodo. Joko Widodo was perceived slow to act by the Civil Society Group in handling the smoke haze because it still followed an old trend in the handling of haze in Indonesia, which is waiting for the smoke to get bigger and then focusing on extinguishing the fire. On the other hand, the central government also slowed in implementing the treatment and evacuation of smoke casualties. While in fact, the devices for emergency response have been prepared after the 
smoke incidence in 1997. Emergency response as health procedures could be referred to the Decree of the Minister of Health of the Republic of Indonesia No. 289 of 2003 about the procedures to control the impacts of air pollution from forest fires. In that regulation, the score of air pollution index above 200 is considered dangerous and there should already be a handling from the government. In smoke pollution index score of 300, there should have conducted the evacuation of children, pregnant women, and vulnerable patients exposed to smoke. However, as regrettable by civil society groups (interview with Ipg, a volunteer of KJMA, January 17, 2016), the prevention of fire and smoke victims in 2015 were becoming more sectoral. The presence of the Regional Disaster Management Agency or BPBD was also considered by civil society groups to have been minimizing the work of emergency response in Provincial and District Health Departments.

The role of BPBD of Jambi Province actually had begun to appear at the end of August 2015. Although the smoke and hotspots on August 20, 2015 had been observed in two districts, namely Muara Jambi and Tanjung Jabung Timur, covering the area of 9,000 hectares, the status of Emergency Preparedness of Forest and Land fires was signed by the Acting Governor of Jambi later on August 27,2015 , and was followed by the statement of the same status by the four districts, namely Muara Jambi, Tanjung Jabung Timur, Tanjung Jabung Barat and Batang. Unfortunately, even though the status of emergency alert existed, BPBD admitted being a lack of equipment, human resources, and funding to do firefighting. Therefore, then BPBD waited for help from the result of coordination between BNPB and the Ministry of Environment and Forestry.

Finally, the help of BNPB came in the form of fire extinguishing operation from the air or water bombing at the end of the first week of September. Three helicopters operated in two extinguishing points, in Medak, the border of Jambi and South Sumatra and in Kumpeh, Muaro Jambi. The overland extinguishing assistance from Indonesian Army, Indonesian Police, and Manggala Agni was also deployed with the constraints of difficult water resources. The society was also involved. Weather Modification Technique was also promised will be done using the provided helicopters. According to a press statement of BPBD in Jambi Province, at the end of September 2015, water bombing activity had been performed 1000 times with a capacity of 2.9 million tons of liters of water and 1000 kilograms of salt deployed to be sowed as rain. However, due to smoke from South Sumatra that was still blown to Jambi, although the hotspots in Jambi had diminished, the Head of Forestry Department in Jambi Province stated to the media in early October that the request to extinguish the fire was taken over by the central government to be more effective for the entire territory of Sumatra. At this point, the actual status of a national disaster was necessary in order to do more comprehensive and well-coordinated fire extinguishing. National disaster status was also expected to be useful for civil society groups to provide care and evacuation for the victims of smoke haze, not only in urban areas but also coordinated throughout the entire remote villages in Indonesia that were exposed to smoke haze.

The result of interviews with IPG and $\mathrm{Pz}$, volunteers of KJMA from the Alliance of Agrarian Reform Movement or AGRA (January 17, 2016), the cases of Lubuk Madrasah, Arang-Arang, and Pangkalan Ranjau Villages in Jambi were their evidence and experience in the field on how slow and very sectoral the government's work in Jambi. The performance of the government through BPBD that focused on performing fire fighting, as if the government forgot the duty for smoke victims treatment was growing. Civil society groups plunged into the villages handing out masks donated by the community for victims of smoke. The volunteers of KJMA worked by themselves in Lubuk Madrasah, with the limited assistance from the officers of a health center in the village. The Health Department of Tebo District made an excuse that they did not have funds for emergency response to treat victims of smoke haze. The request for masks and equipment to treat victims of smoke from the village health center to the Health Department, resulted in cotton and other monthly medical equipment, not the standard N95 masks for air pollution as expected the volunteers and health center officers. Meanwhile, on the other hand, the distribution of standard masks was instead done in urban areas. The evacuation houses that were newly assigned by provincial and municipal governments in Jambi at the end of October 2015, did not reach the villagers who were exposed to more concentrated smoke because they were close to the hotspots, the area of land fires. The policy of 'Evacuation House' in some government institutions, such as the official residence of the Mayor of Jambi, Jambi Provincial Office, Jambi Police Resort City Hall, which were declared to be open to the public, were difficult to access by volunteers of KJMA. KJMA considered the evacuation houses to be late and the access was very limited and was restricted to the public. This halfhearted policy was getting a tougher response from civil society groups in Jambi.

\section{Response of Civil Society Group}

Broadly speaking, there are two groups of civil society in Jambi which stated their stance against land and forest fires and the smoke produced, namely Jambi Coalition against Smoke (KJMA) 
and the Community Campaign of Smoky Jambi. The paradigm of discourse by both groups was the same, which is the smoke occurred due to errors in decision making by the government in the spatial distribution and palm oil and timber plantations expansion. The Community of Smoky Jambi consisted of the combination of individuals who work as journalists, artists and academics, while KJMA contained 26 non-governmental organizations, environmental organizations, mass organizations and social organization, among others: the Alliance of Agrarian Reform Movement (AGRA), Community Conservation IndonesiaWARSI, Forum for Environment Indonesia (WALHI), Women Home Jambi, National Student Front, Jambi Equivalents Foundation, and several other organizations. The combination these two groups was seen on October 28, 2015, when the coalition performed a joint action with 1000 signatures to be sent to the government of Joko Widodo.

Riau social networking civil society was formed because of smoke haze occurred in 2014 . Riau Peat Community Network who preferred the model of mass organization that was formed to bridge the impact of peat fires in Riau with policy makers. However, for the context of Jambi, Jambi Coalition Against Smoke (KJMA) was felt active to be engaged in social action with the division of work is more focused and clear on the incidence of haze in 2015. Most of the KJMA were indeed nongovernmental institutions or organizations which are well established, but some other show sacrifice without preparation and adequate provisions, such as student organizations that join in it.

KJMA was formed as the will of the activists to push the government's attitude to be more responsive and faster towards the effects of smoke haze and encourage permanent settling on the cause of the land fire. Therefore, a series of work was divided into several members of the coalition. E.g. monitoring documentation of hot spots and field checks (ground check) conducted by an established organization in term of field equipment and supplies, while the distribution of masks, daily campaign and assistance for smoke victims' families were done by volunteers who sacrifice their time and their personal interests for volunteerism works.

The work of volunteerism, for example, distributing oxygen to the villages, forming and keeping the residents in the area post office of Governor of Jambi and making cultural actions such as the action Thursday cheerful and cultural stage. KJMA divided the volunteers into several sectors in which teams of media and information that create and spread a press release, a relief team and distribution of medical equipment for the victims of smoke, the health team and evacuation of victims to assistance, as well as data collection and analysis team. Data collected in addition to the monitoring of hotspots, an area of land and forest fires, as well as trying to give birth to an analysis of the costs incurred by the smoke.

The impact of economic loss due to fire in 33 thousand hectares of peatland in Jambi, according to the estimation of civil society groups have caused a total loss of 2.6 trillion rupiah (Interview with Iqbal Zainuddin, activists of KKI WARSI and KJMA in Jambi, January 23, 2016). But the other more severe impacts are the increasing number of casualties, especially children who are sick, who then campaigned by the Coalition Against Smoke Jambi to urge local and national government policies. In fact, the campaign to 'take care of victims of smoke in Jambi' expressed by the community from various places inside and outside the country through social media like facebook and twitter and sent directly to the Twitter account of President Joko Widodo that immediately caused cabinet limited meeting for extinguishing fires in Sumatra (South Sumatra, Jambi and Riau) and Borneo, as well as the presence of Minister of Social Affairs to Jambi as well as the statement of Health Minister related to the victims of smoke. Two cases that became media campaign in Jambi civil society groups in urging the government to treat victims of smoke were the case of two toddlers: Nabila and Digo Pratama Aprillion.

1) Nabila

The Case Nabila (15 months) became a debate between KJMA civil society group and Jambi Provincial Health Department because eventually Nabila passed away. KJMA considered the death of Nabila was due to the increasing of smoke pollution and loudly protested Jambi Provincial Health Department Head who was deemed as not having any intention to protect public health exposed to smoke. KJMA quoted the Head of Jambi Province Health Department in Jambi Independent Newspaper that the death of Nabila was not because of respiratory disease, but due to severe pneumonia illness unrelated to the two months smoke pollution in Jambi (Press Release of KJMA).

The arguments of KJMA in denying the claim by the Head of Provincial Health Department in Jambi then relied on the statement of the Ministry of Health $(\mathrm{MoH})$ of the Republic of Indonesia which the contrary stated that pneumonia is one of the effects of smoke (http://nasional.tempo.co/read/ news/2015/ 09/18/206701732 / pain-victimfog-smoke-of-irritating-to-pneumonia). One of the volunteers of KJMA, who became an informant for this study, Pz of Agrarian Reform Movement Alliance (AGRA) in Jambi (interview on January 17, 2016) stated that the Head of Health Department in Jambi Province was not supposed to make such controversial remarks at that time: 
"As the official facilitated with comfortable facility, vehicle, free from smoke working room, it is expected that the Head of Health Department in Jambi Province to think cleared, became the front row person in protecting the health of Jambi community from the danger of smoke,"

KJMA also flashbacked the statement of Health Department of Jambi Province that had released a data of 60.000 of Jambi Residents suffered from Upper Respiratory Tract Infection. Pz. (interview on 17 January 2016) stated:

"There is no real action. There is no direct guidance nor periodical broadcast. There is no free medication treatment shelter. There is no evacuation measure for pregnant women and children. With naked eye alone, everywhere can be found toddlers and children and even adults who suffered from flu, cough, asphyxiate, eyes and skin irritation,"

IZ, the coordinator of Jambi Women Home (Interview on 18 January 2016) who was also the volunteer of KJMA, added that the danger of smoke was adding more troubles for women, especially for pregnant women. According to her:

"..in addition to threaten their own health, the smoke also threatens the health and even life of the children inside the womb of pregnant women, the mothers are also prone to be blamed by the family and the government with the accusation of negligent in maintaining the health of their children from the danger of smoke."

The statement of Jambi Provincial Health Department Head was somewhat lessened when the Minister of Social Affairs of the Republic of Indonesia visited Sarolangun Jambi. The Minister was present to provide assistance to all victims of smoke, including parents of Nabila. In fact, the parents of Nabila were picked up at night from Jambi to Sarolangun district for the event of providing assistance. The momentum became the confirmation of civil society groups that Nabila was the evident victim of increasingly dangerous smoke.

2) Digo Pratama Aprillion

According to a media release from KJMA, during three months of smoke hitting Jambi, relatively there had not been any maximum effort by the government to deal with victims of smoke among children. The closing of schools was not followed by the treatment and evacuation of smoke victims. The case of Digo Aprillion Pratama (5 months) became another evidence on how to slow the pace of Jambi Government. Digo suffered from the difficulty of breathing, cough, cold and high heat. Digo was initially rushed to Jambi Police Hospitals and given nebulizer relief measure by the doctor. Doctor recommended Digo to be treated. But the lack of funds and fee guarantor made Digo taken back home by his parents.

The volunteers of KJMA heard the complaint of Dian, Digo's mother, on the condition of Digo and the limitation of a fund that made them report the condition to Jambi Provincial Health Department. According to IZ (interview on 18 January 2016), Digo's treatment cost was indeed borne by Health Department, but the administration for the victim of smoke such as Digo was complicated. Therefore, KJMA then urged the policy of free medication and treatment for smoke victims.

The complexity of bureaucracy experienced by Digo, was told by IZ (interview on 18 January 2016):

“Digo's parents were requested by the hospital to get poverty letter from urban-village office. Then the letter was taken to the Sub-district office, then taken again to the City Health Department. If it is that complex, then certainly the service will not be broad and equal. While in fact, it is uncountable how many kids who suffered from the same issue as Digo. And this is worse by the absence of the spreading of information about the procedure for health service access for smoke victims."

The complication on accompanying Digo and Nabila to get health service was directly proportional with the absence of national disaster status towards smoke incidence in 2015. The status, although by many considered as very important, but in the internal of KJMA also caused as debate. Half of KJMA's volunteers considered the national disaster status by eliminating the responsibility of companies which supposed to extinguish the fire in their concession area. Half of KJMA activist suspected that the fire was not incidental, but created for the purpose of land clearing. While the other half of the volunteers considered the earliest national disaster status was very important to help with evacuation and to treat the growing number of smoke victims. Either way, KJMA had produced favorable responses for the wider community, such as the urge for the distribution of masks and standard masks N95, the urge for the government to provide free medication and treatment for the smoke victims, the urge for the Government to have functional and available to public air pollution index gauges, the urge for the government to have evacuation house for children and pregnant women as well as patients with respiratory disorders, and the urge for the policy that is more responsive to emergency by the central government and the provincial government, 
although the official status of national disaster by the Government of Indonesia was yet to be stipulated. KJMA, when this study was written, has succeeded in encouraging the issuance of Regional Regulation in Jambi on Forest and Land Fires (PERDA KARHUTLA), encouraging the business of PT Dyera Hutani Lestari to be suspended, encouraging a legal certainty to palm oil companies and HTI companies which were proven to cause forest fires, and lastly was still struggling for the formation of fact finding mission or fact-finding team from United Nation (UN) to dig the victim views, to find the violators of human rights, the rights to get medical treatment and the rights to get healthy and clean environment and air from 2015 smoke incidence (interview with Ipg, a volunteer of KJMA, 17 January 2016).

\section{Conclusion}

The incidence of smoke haze in 2015 in Jambi, through this study, showed the dilemma of Jambi's Acting Governor to make his decision in managing the cause and impact of smoke haze. The dilemma occurred due to the absence of national disaster status by the Central Government. Regional Disaster Management Agency and Regional Apparatus Woking Unit were also unable to act faster without national disaster status. On the other hand, civil society groups seemed to play an active role in helping on their own in the treatment of haze victims' health and to urge the local government not to focus only on firefighting. The urge from civil society groups so that local government could make responsive policy related to the impact of smoke haze and its cause eventually resulted: the realization of Local Regulation on Forest and Land Fires (PERDA KARHUTLA); make some companies get strong warning status so their licenses were suspended; as well as to inherit long-term method and strategy for civil society and policy makers in the managing of smoke haze impact in Jambi.

This study suggests that the determination of smoke haze status that hit some province in Indonesia as a national disaster, will not reduce the nature of smoke disaster as a man-made disaster. Determining the status of smoke disaster not as a national disaster requires a clear disaster task force determination at the regional level. BPBD became sectoral without synergy with other Regional Apparatus Working Units, especially on the Department of Health and the District Government. If possible, the task force, both BPBD and the combination of SKPD are given the freedom of bigger authority and funding in managing the impact of smoke haze and the extinguishing of smoke sources, especially on the status of 'emergency alert'. If possible the treatment for smoke victims must be more maximized, and the prevention of forest and land fires are urgent to be implemented at all cost so that the incidence of smoke will never happen again on the next dry season and El Nino.

\section{REFERENCES}

Alamsyah, Z. (2002). Implikasi Pengembangan Perkebunan Kelapa Sawit terhadap PAD dan Masyarakat Adat. Presentation, Jambi.

Arfan,. (2007). Perubahan Sosioekonomi Masyarakat di Sekitar Perladangan Kelapa Sawit Berskala Besar di Sarolangun, Provinsi Jambi Indonesia (Master Thesis). Universiti Kebangsaan Malaysia.

Artharini, I. (2015). Konsentrasi Titik Api di Sumatera Selatan dan Jambi. BBC Indonesia., from http://www.bbc.com/indonesia/berita indonesia/2015/08/150827_indonesia_ jambi_titikapi

Bram, D. (2011). Pertanggungjawaban Negara Terhadap Pencemaran Lingkungan Transnasional. Jurnal Hukum Ius Quia Iustum, 18(2), 193-211.

Bram, D. (2013). Kejahatan Korporasi dalam Pencemaran Lintas Batas Negara: Studi Pencemaran Kabut Asap Kebakaran Hutan di Indonesia. Law Review, 11(3), 377-393.

Daulay, A. (2004). Regional Autonomy and Sustainable Development in Indonesia: the Case of Oil Palm Development in Jambi Province (Master Thesis). University of Queensland.

Dennis, R., Erman, A., Stolle, F., \& Applegate, G. (2000). The Underlying Causes and Impacts of Fires in South-East Asia Site 5. Danau Sentarum, West Kalimantan Province, Indonesia. Bogor: CIFOR, ICRAF, USAID, USFS.

Fajriah, L. (2015). Awas, El Nino Ganggu Indonesia Hingga November. SINDOnews. com., from http://nasional.sindonews.com/ read/1013740/15/awas-el-nino-gangguindonesia-hingga-november-1434527806

Fardiaz, S. (1992). Polusi Air \& Udara. Yogyakarta: Penerbit Kanisius.

Heil, A. \& Goldammer, J. (2001). Smoke-haze Pollution: a Review of the 1997 Episode in Southeast Asia. Regional Environmental Change, 2(1), 24-37. http://dx.doi.org/10.1007/ s101130100021

Ilahude, A. \& Nontji, A. (1999). Oseanografi Indonesia dan Perubahan Iklim Global (ElNino dan LaNina). Makalah Lokakarya "Kita dan Perubahan Iklim Global: Kasus El Nino dan La Nina. Akademi Ilmu Pengetahuan Indonesia. Presentation, Jakarta.

Inge, N. (2015). Gubernur Sumsel Yakin Kabut Asap Palembang Berakhir Oktober 2015. liputan6.com., from http://news.liputan6. $\mathrm{com} / \mathrm{read} / 2329720 /$ gubernur-sumselyakin-kabut-asap-palembang-berakhiroktober-2015

Jenito, \& Saturi, S. (2015). Kabut Asap Makin 
Parah, Jokowi Akhirnya Blusukan ke Kalteng. Mongabay.co.id., from http://www.mongabay. co.id/2015/09/24/kabut-asap-parah-jokowiakhirnya-blusukan-ke-kalteng/

Jogi Sirait, J. (2013). Wilmar Jual Asiatic Persada, Kemitraan Dengan Suku Bathin Sembilan Buyar / Mongabay.co.id. Mongabay.co.id., from http:// www.mongabay.co.id/2013/10/04/wilmarjual-asiatic-persada-kemitraan-dengan-sukubathin-sembilan-buyar /

Koe, L., Arellano, A., \& McGregor, J. (2001). Investigating the Haze Transport from 1997 Biomass Burning in Southeast Asia: Its Impact upon Singapore. Atmospheric Environment, 35(15), 2723-2734. http:// dx.doi.org/10.1016/s1352-2310(00)00395-2

Lamban Atasi Kabut Asap, Presiden Panggil PLT Gubernur Riau ke Jakarta. (2015). Riauterbit. com., from http://riauterbit.com/mobile/ detailberita/607/lamban-atasi-kabut-asap,presiden-panggil-plt-gubernur-riau-kejakarta.html

Locher-Scholten, E. (2008). Kesultanan Sumatra dan Negara Kolonial: Hubungan Jambi-Batavia: 1830-1907 dan Bangkitnya Imperialisme Belanda. Jakarta: KITLV.

Ministry of Health. (2003). Decree of the Minister of Health of the Republic of Indonesia No. 289 of 2003 about the Procedures to Control the Impacts of Air Pollution from Forest Fires. Jakarta: Ministry of Health.

Murty, T., Khandekar, M., Baird, W., \& Scott, D. (2000). The 1997 El Niño, Indonesian Forest Fires and the Malaysian Smoke Problem: A Deadly Combination of Natural and Man-Made Hazard. Natural Hazards, 2(2-3), 131-144. http://dx.doi.org/10.1023/A:1008141003518

Muslimah, S. (2015). Masyarakat dan Prajurit TNI di Jambi Gelar Salat Istisqa. detiknews., from http://news.detik.com/berita/3022848/ masyarakat-dan-prajurit-tni-di-jambi-gelarsalat-istisqa

Oosterman, A. \& Widayat, D. (2001). The Impact of Fires on Local Economies: the Case of Batu Ampar. Jakarta: Berau Forest Management Project.

Ostermann, K. \& Brauer, M. (2001). Air Quality During Haze Episodes and Its Impact on Health. In P. Eaton \& M. Radojević, Forest Fires and Regional Haze in Southeast Asia (1st ed., pp. 195-226). New York: Nova Science Publishers.
Profil Jaringan Masyarakat Gambut Riau. (2014). Jmgriau.blogspot.co.id., from http://jmgriau. blogspot.co.id/2014/11/profil-jaringanmasyarakat-gambut-riau.html

Qadri, S. (2001). Fire, Smoke, and Haze. Manila: Association of Southeast Asian Nations and Asian Development Bank.

Sargeant, H. (2001). Vegetation Fires in Sumatra Indonesia. Oil Palm Agriculture in the Wetlands of Sumatra: Destruction or Development?. Palembang: Ministry of Forestry and European Commission.

Saturi, S. \& Jenito,. (2015). Kabut Asap Mulai Kepung Singapura dan Malaysia. Mongabay. co.id. Retrieved 30 May 2016, from http:// www.mongabay.co.id/2015/09/12/ kabut-asap-mulai-kepung-singapura-danmalaysia/?relatedposts_hit=1\&relatedposts origin $=41169$ \&relatedposts_position $=2$

Sudarmadji, T. (2001). Impact of Logging and Forest Fires on Soil Erosion in Tropical Humid Forest in East Kalimantan. In S. Kobayashi, J. Turnbull, T. Toma, T. Mori \& N. Majid, Rehabilitation of degraded tropical forest ecosystems: workshop proceedings (1st ed., pp. 35-44). Bogor, Indonesia: CIFOR.

Suyastri, C. (2009). Transboundary Environmetal Issue antara Indonesia, Malaysia dan Singapura: Studi Kasus Kabut Asap di Riau (Master Thesis). Universitas Gadjah Mada.

Tacconi, L. (2003). Kebakaran Hutan di Indonesia: Penyebab, Biaya, dan Implikasi Kebijakan. Bogor: CIFOR.

Tarigan, M. (2015). Derita Korban Kabut Asap: dari Iritasi hingga Pneumonia. Tempo Nasional., from http://nasional.tempo.co/ read/news / 2015 /09/18/206701732/ derita-korban-kabut-asap-dari-iritasi-hinggapneumonia

Van Nieuwstadt, M., Sheil, D., \& Kartawinata, K. (2001). The Ecological Consequences of Logging in the Burned Forests of East Kalimantan, Indonesia. Conservation Biology, 15(4), 1183-1186. http://dx.doi.org/10.1046/ j.1523-1739.2001.0150041183.x

Wicaksono, M. (2015). Udara Palangkaraya 5 Kali Lipat Berbahaya. KOMPAS.com., from http://regional.kompas.com/ read / 2015 / 09/23/20262261/Udara. Palangkaraya.5.Kali.Lipat.Berbahaya 